RESIDENT

\& FELLOW

SECTION

Section Editor

Mitchell S.V. Elkind,

MD, MS

Shane Wells, MD

Ashok Srinivasan, MD

Address correspondence and reprint requests to Dr. Ashok Srinivasan, Division of

Neuroradiology, Department of Radiology, University of

Michigan Health System, 1500 E Medical center drive, Ann Arbor, MI 48109

ashoks@med.umich.edu

\section{Teaching NeuroImages: \\ Incidental retroclival mass in a patient with headache}

Figure MRI
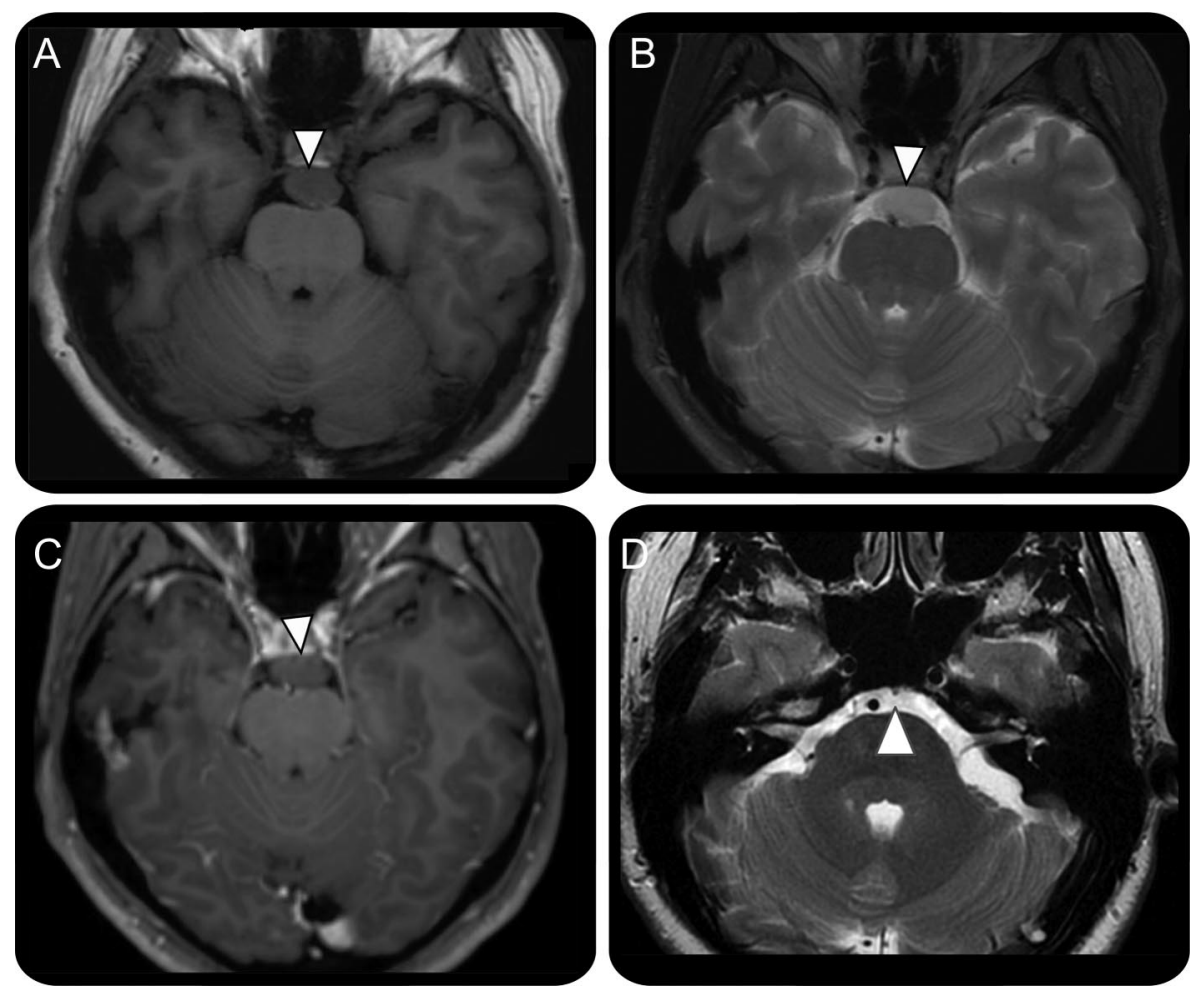

On a 3T magnet, an ovoid, circumscribed, retroclival mass is seen, which demonstrates intermediate T1-weighted (A), mildly hyperintense T2-weighted (B) signal with no contrast enhancement (C). On the axial T2-weighed sequence, there is an osseous stalk arising from the dorsal aspect of the clivus and extending into the mass, confirming the diagnosis of ecchordosis physaliphora (D).

A 46-year-old woman presented with chronic headaches and facial numbness. Her clinical examination was unremarkable. MRI demonstrated a nonenhancing retroclival mass with intermediate T1-weighted and hyperintense T2-weighted signal (figure, A-C). While chordoma, chondrosarcoma, dermoid, and metastasis were possibilities, demonstration of an osseous stalk (figure, D) confirmed the diagnosis of ecchordosis physaliphora (EP).

Recognition of EP, a benign notochordal remnant, on imaging can avoid unnecessary biopsy. Presence of an osseous stalk is considered pathognomonic and can be seen on both MRI and CT. ${ }^{1,2}$ While usually asymptomatic, it can present with headache, visual disturbances, gait imbalance, and paresthesias. ${ }^{1,2}$

\section{REFERENCES}

1. Ciarpaglini R, Ernesto P, Mazzatenta D, Amrosini-Spaltro A, Sciarretta V, Frank G. Intradural clival chordoma and ecchordosis physaliphora: a challenging differential diagnosis: case report. Neurosurgery 2009;64:E387-E388.

2. Mehnert F, Beschorner R. Kuker W, Hahn U, Nagele T. Retroclival ecchordosis physaliphora: MR imaging and review of the literature. Am J Neuroradiol 2004;25:18511855.

From the Department of Radiology, University of Michigan Health System, Ann Arbor.

Disclosure: The authors report no disclosures. 


\section{Neurology}

\section{Teaching NeuroImages: Incidental retroclival mass in a patient with headache Shane Wells and Ashok Srinivasan}

Neurology 2010;75;e93

DOI 10.1212/WNL.0b013e318200d7cc

\section{This information is current as of December 6, 2010}

\section{Updated Information \& Services}

References

Subspecialty Collections

Permissions \& Licensing

\section{Reprints}

including high resolution figures, can be found at: http://n.neurology.org/content/75/23/e93.full

This article cites 2 articles, 0 of which you can access for free at: http://n.neurology.org/content/75/23/e93.full\#ref-list-1

This article, along with others on similar topics, appears in the following collection(s):

All Headache

http://n.neurology.org/cgi/collection/all_headache

CT

http://n.neurology.org/cgi/collection/ct

MRI

http://n.neurology.org/cgi/collection/mri

Information about reproducing this article in parts (figures,tables) or in its entirety can be found online at:

http://www.neurology.org/about/about_the_journal\#permissions

Information about ordering reprints can be found online:

http://n.neurology.org/subscribers/advertise

Neurology ${ }^{\circledR}$ is the official journal of the American Academy of Neurology. Published continuously since 1951, it is now a weekly with 48 issues per year. Copyright Copyright (? 2010 by AAN Enterprises, Inc.. All rights reserved. Print ISSN: 0028-3878. Online ISSN: 1526-632X.

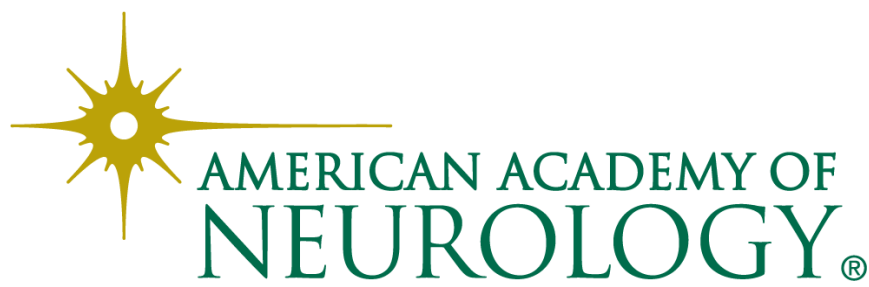

